\title{
Occupational risk perception: A scale development study
}

\author{
Berna Aksoy, Eylem Pasli Gurdogan* \\ Department of Nursing, Trakya University Faculty of Health Sciences, Edirne, Turkey
}

Received: November 19, 2018

DOI: $10.5430 /$ jnep.v9n4p98
Accepted: December 12, 2018 Online Published: December 28, 2018

URL: https://doi.org/10.5430/jnep.v9n4p98

\begin{abstract}
Background and objective: The determination of occupational risk perception is the basic tool for making attitude and behaviour changes, for improving health and safety sense. In the present paper, we aim to develop a reliable and valid occupational risk perception measurement.

Methods: Cross-sectional survey design was used in the 2015-2016 academic year with a sample of involved students studying in the 2nd, 3rd and 4th grades $(\mathrm{N}=439) .423$ nursing students was recruited in the study. We evaluated the reliability and validity, consistency by using explanatory and confirmatory factor analysis, Cronbach's alpha values and The Pearson correlation coefficients of the new scale.

Results: After the explanatory factor analysis the scale was composed of 17 items and 3 subscales which named psychological and ergonomic risks subscale and person and institution-related risks subscale and the physical environment subscale. The Cronbach's alpha of the scale was 0.826 . The scale's confirmatory factor analysis showed good conformance.

Conclusions: The scale is a valid and reliable measurement tool for measuring occupational risk perceptions among nursing students. This scale is used to determine the occupational risk perceptions in the field of healthcare.
\end{abstract}

Key Words: Construct validity, Factor analysis, Nursing students, Occupational risk, Scale development

\section{INTRODUCTION}

Nursing staff constitute a crucial component of healthcare systems and they give direct care to patients and spend more time with them as compared to other healthcare workers. Therefore, the probability of exposure to occupational risks, such as physical, biological, chemical, psychological, and ergonomic threats, is higher among nurses. ${ }^{[1-4]}$

Nurses experience long working hours, extra workload, time pressure, complicated tasks, insufficient rest periods, physically poor working conditions, stress, standing for long hours, insufficient sleep, and erratic eating schedules while on duty. ${ }^{[5]}$ Furthermore, nurses are often subject to occupa- tional threats such as infections, sharp object injuries, exposure to drugs, blood-body fluid smear, careless behaviours of employees, lack of ergonomic design, musculoskeletal system injuries and exposure to violence that may result in disability, loss of health or life, or income poverty. ${ }^{[6]}$ A study reported that injuries from needles and sharp objects were observed at the rate of $68.5 \%$ among healthcare professionals. ${ }^{[7]}$

Nursing students are exposed to same risks as staff nurses while performing clinical tasks, which may lead to adverse health effects such as violent, aggressive behaviour and sharps injur. ${ }^{[8-10]}$ Talas reported that, nursing students have

\footnotetext{
* Correspondence: Eylem Pasli Gurdogan; Email: e.gurdogan@gmail.com; Address: Department of Nursing, Trakya University Faculty of Health Sciences, Edirne, Turkey.
} 
high levels of perceived stress, lack of knowledge and limited experience during clinical training so nursing students are at greater risk of percutaneous injuries. ${ }^{[11]}$ Magnavita and Heponiemi reported that $43 \%$ of nurses and $34 \%$ of nursing students experienced physical or verbal violence in the clinical environment. ${ }^{[12]}$ McCarthy and Britton reported that $27 \%$ of nursing students were exposed to non-sterile occupational injuries, some of which resulted in HBV and HIV transmission. ${ }^{[13]}$

In the study of Dante et al., a total of 239 cases of injury exposures were reported by nursing students whose 187 reported being contaminated by body fluids. ${ }^{[14]}$ In the study conducted by Elijedi involving nursing students, $48.0 \%$ of the participants reported frequent irritation in eyes, skin and nose due to the inhalation of chemical particles, touching disinfectants and contaminated materials and splashes of irritating fluids, and $43 \%$ of students reported allergic reaction to Latex. ${ }^{[15]}$ Braeckman et al. stated that medical students showed a general lack of awareness regarding exposure to occupational hazards, and inadequate knowledge of precautionary measures. ${ }^{[8]}$

It is important that students have information and awareness about occupational risks. In order to raise awareness, risk perceptions should be determined at first. The determination of occupational risk perception is the basic tool for making attitude and behaviour changes, for improving health and safety sense, and for planning rational interventions.

In the nursing literature, there is no measurement tool used for measuring the occupational risk perceptions. However, this is now considered a necessity when occupational health and safety are increasingly gaining importance. This study aimed to develop and validate the "Occupational Risk Perception Scale" (ORPS), which assesses perception of the nursing students' about occupational risks.

\section{METHOD}

\subsection{Study design}

This study designed a multi-method approach to develop and validate the ORPS, using qualitative and quantitative data collection methods. We used the following steps to construction of the psychometric properties of the ORPS.

\subsection{Setting and sample}

The sample size calculation was performed using method which included three rules, the $5 \mathrm{~s}, 10 \mathrm{~s}$ and $100 \mathrm{~s}$ rule and we included at least five individuals for each item in order to perform the factor analysis. ${ }^{[16]}$

This study was conducted in October 2015 to May 2016, at Trakya University, Faculty of Health Science, Department of Published by Sciedu Press
Nursing in Turkey. The study population involved nursing students studying in the $2 \mathrm{nd}, 3 \mathrm{rd}$ and 4 th grades $(\mathrm{n}=439)$ and participating in clinical practice education at hospital. Student profile of the university planned for the study consists of students who are coming from the different regions and culture of Turkey for nursing education. In addition, $10 \%$ quota is allocated to students from the Balkan countries to receive nursing education every year.

The data were collected using face-to-face interview system with the study participants. Data of the study gathered from 423 nursing students. Of 423 nursing students, 58 students were asked to respond to the questionnaires twice, at an interval of three weeks, in order to examine the stability of the scale.

We determined inclusion criteria, which students should be older than 18 years, and must be volunteer, for the study.

\subsection{Ethical consideration}

The informed voluntary consent form was read and aim of the study was explained to the voluntary. This study was approved by The Ethics Committee of the Faculty of Medicine of Trakya University (Approval no.: TÜTF-BAEK 2015/141). We obtained institutional permissions in order to carry out this research.

The verbal and written consent for participation were obtained from students.

\subsection{Instruments}

Student information form: Student Information Form was improved by referring to the literature. It consisted of ten questions including the student's sociodemographic features, gender, class, occupational risk education, inoculation against hepatitis B, encounter with professional accidents at internship. ${ }^{[1,4,10,12-15]}$

Occupational Risk Perception Scale: The ORPS was used to determine the occupational risk perceptions of the nursing students. The scale consisted of 17 items, which were rated on a five-point Likert-type scale ranging from 1 to 5 (" $1=$ No idea", " 2 = Does not pose a risk", "3 = Low risk", " $4=$ Moderate risk", " $5=$ High risk"). Higher scores indicated a high awareness and high perception of occupational risks in nursing students.

\subsection{Stages of study \\ 2.5.1 Forming item pool}

A comprehensive analyses should be performed for the created new scale statements. The scale items should constitute and represent all aspects of dimensions of the measured variables. ${ }^{[16]}$ We reviewed literature and found studies defining 
on occupational risk perception, in this way items pool of the scale were formed. Then we formed dimensions to determine the occupational risk perception and the formed items were associated with the dimensions. ${ }^{[7,12,17,18]}$

\subsubsection{Forming specialist opinions}

The literature suggests that a draft scale to determine the content validity should be evaluated by at least 10 experts. ${ }^{[16]}$ According to this rule, the 80-item pool was developed and the opinions of 20 specialists were received. These experts were consisted of nurses, occupational safety experts, nursing education and occupational health professors. The specialists evaluated each item of draft scale according to three-point scale ( 1 = Appropriate/necessary, 2 = Inappropriate/unnecessary, 3 = Needs improvement/correction). The Lawshe technique was used to calculate the Content Validity Ratio (CVR). The CVR of each item was calculated according to the feedback from the experts. Consequently, 30 items that were below the minimum .42 CVR value, were excluded from the draft scale. ${ }^{[19]}$ Finally, a 50-item pool was choosen.

\subsubsection{Forming preliminary test}

The draft scale should apply to 10-20 individuals who were not included in the sample which had similar features after experts informed the opinions. ${ }^{[16]}$ The version of 50 items draft scale was applied to 20 nursing students and got their feedback. As a result of feedback, minor changes were made to the wording of the items. Then we applied the draf scale to the larger group.

\subsection{Data collection}

We wanted them to fill out the Student Information Form and Occupational Risk Perception Scale after consents of volunteer students were obtained. The draft scale was took approximately 15 minutes. The researchers collected the data and interviewed students who met our criteria. 16 students were excluded from the study, because they were not willing to participate in the study and the scale filling rate was not $100.0 \%$. The participation rate of the study was $96.35 \%(423$ students). Of 423 nursing students, 58 students were asked to respond to the questionnaires twice, at an interval of three weeks, in order to examine the stability of the scale. Each student was asked to use an ID number or nickname for to match their questionnaires. Finally, validity and reliability of the data were conducted with 365 nursing students.

\subsection{Data analysis}

SPSS version 20.0 statistical software (IBM SPSS Inc., Chicago, IL, USA) and Lisrel 8.8 program were used in the assessment of the data. Content Validity Ratio (CVR), explatory factor analysis (EFA), confirmatory factor analysis (CFA) were used for validity analysis. Internal consistency, split half method, item analysis and test-retest methods were used to examine the reliability of the scale. The CVR was used to determine the content validity of the specialists. The Lawshe technique was used to calculate the CVR. The CVR of each item were calculated according to the feedback from the experts. Items that were below the minimum .42 CVR value, were excluded from the draft scale. ${ }^{[19]}$ The adequacy of the data for factor analysis was evaluated by using the Kaiser-Meyer-Olkin (KMO) test and Bartlett's test. When determining the factor number, the eigenvalue was taken greater than 1.00. Items with factor loading $>0.40$ were selected to ensure a stable factor structure with adequate sample size and the ratio of participants and variables in this study. Construct validity was examined through EFA and CFA. The construct validity of the scale was assessed by EFA and the varimax rotation method was applied for the approximation of the simple structure. The compatibility status of the created model was tested by the CFA. Chi-square test, Goodness of fit index (GFI, normal value > .95; acceptable values > .90), comparative fit index (CFI), root mean square error of approximation (RMSEA, normal value < .05; acceptable value $<.08$ ), and normal fit index (NFI, normal value $>.95$; acceptable value $>.90$ ) was conducted to verify the model. ${ }^{[16]}$

\section{RESULTS}

\subsection{Sample characteristics}

The mean age of the participants was 21.16 years $(\mathrm{SD}=$ 1.54). The majority of the students were female $(92.3 \%)$ and $34.8 \%$ were 4 th grade students. Students who experienced accidents during clinical practices were $42.2 \%$ and $48.5 \%$ of the students stated that information about occupational risks during their training was insufficient.

\subsection{Content validity}

The CVR of each item was calculated according to the feedback from the experts. Consequently, 30 items that were below the minimum .42 CVR value, were excluded from the draft scale. ${ }^{[19]}$ Finally, a 50-item pool was choosen.

\subsection{Construct validity}

The Kaiser-Meyer-Olkin measure of sampling adequacy was .837. In addition, Bartlett's test was statistically significant with $\chi^{2}=1894.9$ and $p<.001$. The construct validity of the scale was assessed by EFA and the varimax rotation method. After researcher completed the desired rotation, he/she must inspect the factor pattern matrix and decide what magnitude of loading is acceptable for variables to define factors. Items with factor loading $>0.40$ were selected to ensure a stable factor structure with adequate sample size and the ratio of participants and variables in this study. Thirty-three 
items with a factor load $<0.40$ were eliminated from the scale. When determining the factor number, the eigenvalue was taken as 1.00; therefore, the scale consisted of three subdimensions. Thus, it was determined that the scale consisted of 17 items and three sub-dimensions.

The first sub-dimension comprised seven items was named psychological and ergonomic risks, the second subdimension comprised five items was named person and institution-related risks and the third sub-dimension comprised five items was named risks related to the physical environment. These three-factorial structure explained $51.55 \%$ of the variance (see Table 1).

Table 1. Factor loading of each item of ORPS $(\mathrm{N}=365)$

\begin{tabular}{|c|c|c|c|c|c|c|c|}
\hline \multirow{2}{*}{$\begin{array}{l}\text { Item } \\
\text { No }\end{array}$} & \multirow[b]{2}{*}{ Item } & \multicolumn{3}{|c|}{ Factor loading } & \multirow{2}{*}{$\begin{array}{l}\text { Eigen } \\
\text { value }\end{array}$} & \multirow{2}{*}{$\begin{array}{l}\text { Explained } \\
\text { Variance } \\
(\%)\end{array}$} & \multirow{2}{*}{$\begin{array}{l}\text { Cumulative } \\
\text { variance } \\
(\%)\end{array}$} \\
\hline & & $\begin{array}{l}\text { Factor } \\
1\end{array}$ & $\begin{array}{l}\text { Factor } \\
2\end{array}$ & $\begin{array}{l}\text { Factor } \\
3\end{array}$ & & & \\
\hline 20 & An excessive workload in nurses in terms of occupation & .753 & .087 & .106 & \multirow{7}{*}{4.88} & \multirow{7}{*}{28.74} & \multirow{7}{*}{28.74} \\
\hline 19 & More than 9-hour shifts in nurses in terms of occupation & .745 & .084 & .099 & & & \\
\hline 22 & $\begin{array}{l}\text { Working while standing for a long time in nurses in terms of } \\
\text { occupation }\end{array}$ & .697 & .048 & .164 & & & \\
\hline 18 & $\begin{array}{l}\text { Work environment-related stress in nurses in terms of } \\
\text { occupation }\end{array}$ & .693 & .139 & .071 & & & \\
\hline 27 & $\begin{array}{l}\text { Psychological pressure applied by administrators in nurses in } \\
\text { terms of occupation }\end{array}$ & .680 & .171 & .172 & & & \\
\hline 21 & $\begin{array}{l}\text { Patient transporting and lifting in nurses in terms of } \\
\text { occupation }\end{array}$ & .667 & .077 & .125 & & & \\
\hline 28 & $\begin{array}{l}\text { The lack of lunch break and resting breaks in nurses in terms } \\
\text { of occupation }\end{array}$ & .638 & .108 & .183 & & & \\
\hline 50 & $\begin{array}{l}\text { Not wearing clothes/shoes appropriate for the work } \\
\text { environment in nurses in terms of occupation }\end{array}$ & .068 & .710 & .078 & \multirow{5}{*}{2.08} & \multirow{5}{*}{12.26} & \multirow{5}{*}{41.01} \\
\hline 48 & $\begin{array}{l}\text { The use of jewellery (ring. bracelet) in the work environment } \\
\text { in nurses in terms of occupation }\end{array}$ & .065 & .706 & .097 & & & \\
\hline 45 & $\begin{array}{l}\text { Not giving orientation training to the personnel in nurses in } \\
\text { terms of occupation }\end{array}$ & .291 & .694 & .030 & & & \\
\hline 46 & $\begin{array}{l}\text { The ineffective use of waste boxes in nurses in terms of } \\
\text { occupation }\end{array}$ & .135 & .675 & .050 & & & \\
\hline 47 & $\begin{array}{l}\text { Not taking preventive measures in the preparation of } \\
\text { medicines in nurses in terms of occupation }\end{array}$ & .192 & .666 & .033 & & & \\
\hline 3 & $\begin{array}{l}\text { The humidity level of the work environment in nurses in } \\
\text { terms of occupation }\end{array}$ & .059 & .121 & .805 & \multirow{5}{*}{1.79} & \multirow{5}{*}{10.54} & \multirow{5}{*}{51.55} \\
\hline 1 & $\begin{array}{l}\text { Factors related to the temperature of the work environment in } \\
\text { nurses in terms of occupation }\end{array}$ & .073 & .012 & .707 & & & \\
\hline 2 & $\begin{array}{l}\text { Factors related to the floor of the work environment in nurses } \\
\text { in terms of occupation }\end{array}$ & .016 & .110 & .668 & & & \\
\hline 5 & $\begin{array}{l}\text { Reflections and glinting arising from the glass. floor. etc. in } \\
\text { the work environment in nurses in terms of occupation }\end{array}$ & .160 & .008 & .668 & & & \\
\hline 4 & $\begin{array}{l}\text { Noise level in the work environment in nurses in terms of } \\
\text { occupation }\end{array}$ & .287 & .050 & .640 & & & \\
\hline
\end{tabular}

The compatibility status of the created model was tested by the CFA. To verify the goodness of fit and the validity of the models, it was considered the results both the $\chi^{2}$ test and the descriptive goodness of fit measures. According to results of the CFA, the value of the similarity ratio $\chi^{2}$ was found to be 276.87 , the df value was $116(p<.001)$, and the $\chi^{2} / \mathrm{df}$ ratio was 2.38 . The degree of freedom, root mean square error of approximation (RMSEA) showed a value of 0.062 , within the accepted fit range and within the recommended levels. The Goodness of Fit Index (GFI) showed a value of 0.92. Regarding the incremental fit indexes, the Normed Fit Index (NFI) showed a value of 0.94, and the Comparative Fit Index (CFI) showed a value of 0.95 (see Figure 1). 


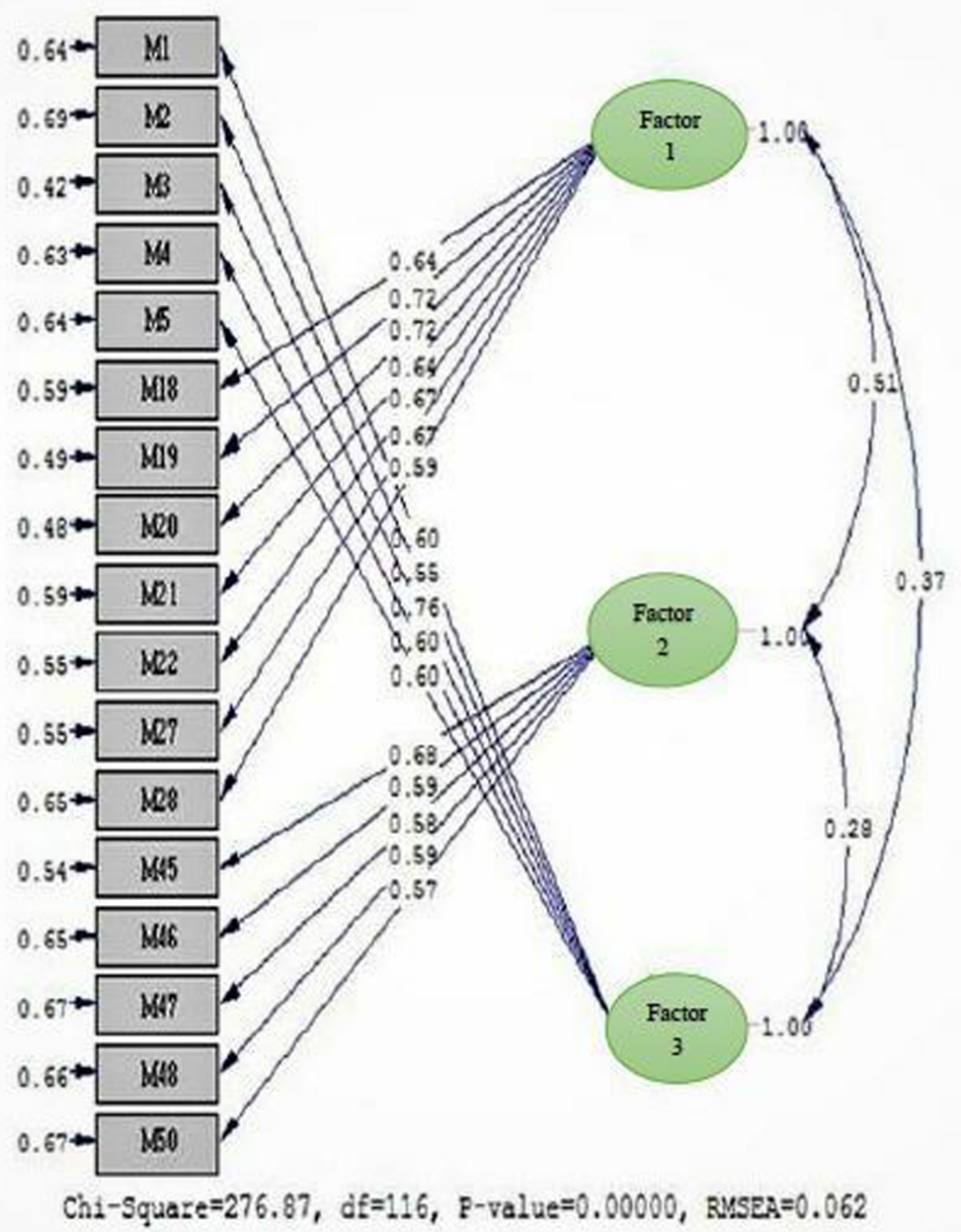

Figure 1. Path diagram for ORPS by confirmatory factor analysis $(\mathrm{n}=365)$

\subsection{Reliability analyses}

The Cronbach's alpha of the ORPS scale was 0.826. In addition, Cronbach's alpha value of the psychological and ergonomic risks subscale was 0.835 ; person and institutionrelated risks subscale was 0.750 and risks related to the physical environment scale was 0.755 . It was found out that the mean scores of the scale items ranged from 3.23 to 4.71 (on a scale of 1-5) and the item-total correlations ranged from 0.47 to 0.64 (see Table 2).

\subsection{Stability}

The stability of the scale was established by measuring the test-retest reliability. A total of 58 nursing students were interviewed again three weeks later and the data were collected. The Pearson correlation coefficient between the scores obtained over the three-week interval was $r=.896,(p=.000)$.

\section{Discussion}

The aim of this study was to develop a valid and reliable instrument to assess the occupational risk perceptions in nursing students. According to results the 17-items ORPS comprised three factors: psychological and ergonomic risks, person and institution-related risks and risks related to the physical environment. Psychometric measurements showed, ORPS represent a suitable instrument for determine the occupational risk perceptions of the nursing students.

Validity and reliability are the most important qualities in a scale. The results of the studies should be reproducible to determine whether it is reliable. ${ }^{[20]}$ The experts in the field tested the scale in terms of face validity and content validity. Thus, a total of 20 experts were asked to assess the draft scale and the opinion of experts was evaluated through CVR, which was proposed by Lawshe. ${ }^{[21]}$ According to this technique, the rate of CVR for 20 experts is $0.42 .{ }^{[21]}$ Thereafter, each item was analysed for the mean scores. 30 items were below the minimum value of 0.42 and the draft was subtracted from the scale. The construct validity study of the scale was continued with the remaining 50-item draft scale.

The construct validity of the scale was assessed through fac- 
torial analysis. In order to perform a good factor analysis, it coefficient as 0.83 which was considered good and Bartlett's is desired that the KMO value is between 0.80 and 1.00. The test result as $\chi^{2}=1,894.9, p=.000$ which was found to test results falling in the range of 0.80-0.99 are considered be extremely significant. These findings showed that it was to be very good. ${ }^{[16]}$ The present study showed the KMO feasible to conduct a factor analysis.

Table 2. Internal reliability of ORPS $(\mathrm{N}=365)$

\begin{tabular}{|c|c|c|c|c|c|c|}
\hline Factor & $\begin{array}{l}\text { Item } \\
\text { No }\end{array}$ & Item & Mean \pm SD & $\begin{array}{l}\text { Corrected } \\
\text { item-total } \\
\text { correlation }\end{array}$ & $\begin{array}{l}\text { Alpha if } \\
\text { item } \\
\text { deleted }\end{array}$ & $\begin{array}{l}\text { Cronbach's } \\
\alpha\end{array}$ \\
\hline \multirow{7}{*}{1} & 20 & An excessive workload in nurses in terms of occupation & $4.71 \pm 0.51$ & .511 & .815 & \multirow{7}{*}{.835} \\
\hline & 19 & More than 9-hour shifts in nurses in terms of occupation & $4.63 \pm 0.59$ & .499 & .814 & \\
\hline & 22 & $\begin{array}{l}\text { Working while standing for a long time in nurses in terms } \\
\text { of occupation }\end{array}$ & $4.56 \pm 0.58$ & .484 & .815 & \\
\hline & 18 & $\begin{array}{l}\text { Work environment-related stress in nurses in terms of } \\
\text { occupation }\end{array}$ & $4.41 \pm 0.73$ & .479 & .814 & \\
\hline & 27 & $\begin{array}{l}\text { Psychological pressure applied by administrators in nurses } \\
\text { in terms of occupation }\end{array}$ & $4.44 \pm 0.74$ & .547 & .810 & \\
\hline & 21 & $\begin{array}{l}\text { Patient transporting and lifting in nurses in terms of } \\
\text { occupation }\end{array}$ & $4.48 \pm 0.70$ & .458 & .815 & \\
\hline & 28 & $\begin{array}{l}\text { The lack of lunch break and resting breaks in nurses in } \\
\text { terms of occupation }\end{array}$ & $4.40 \pm 0.79$ & .483 & .813 & \\
\hline \multirow{5}{*}{2} & 50 & $\begin{array}{l}\text { Not wearing clothes/shoes appropriate for the work } \\
\text { environment in nurses in terms of occupation }\end{array}$ & $4.18 \pm 0.85$ & .359 & .821 & \multirow{5}{*}{.750} \\
\hline & 48 & $\begin{array}{l}\text { The use of jewellery (ring, bracelet) in the work } \\
\text { environment in nurses in terms of occupation }\end{array}$ & $4.01 \pm 0.85$ & .365 & .820 & \\
\hline & 45 & $\begin{array}{l}\text { Not giving orientation training to the personnel in nurses in } \\
\text { terms of occupation }\end{array}$ & $4.13 \pm 0.83$ & .468 & .814 & \\
\hline & 46 & $\begin{array}{l}\text { The ineffective use of waste boxes in nurses in terms of } \\
\text { occupation }\end{array}$ & $4.48 \pm 0.73$ & .369 & .820 & \\
\hline & 47 & $\begin{array}{l}\text { Not taking preventive measures in the preparation of } \\
\text { medicines in nurses in terms of occupation }\end{array}$ & $4.65 \pm 0.62$ & .399 & .818 & \\
\hline \multirow{6}{*}{3} & 3 & $\begin{array}{l}\text { The humidity level of the work environment in nurses in } \\
\text { terms of occupation }\end{array}$ & $3.49 \pm 0.91$ & .453 & .815 & \multirow{5}{*}{.755} \\
\hline & 1 & $\begin{array}{l}\text { Factors related to the temperature of the work environment } \\
\text { in nurses in terms of occupation }\end{array}$ & $3.23 \pm 1.00$ & .348 & .823 & \\
\hline & 2 & $\begin{array}{l}\text { Factors related to the floor of the work environment in } \\
\text { nurses in terms of occupation }\end{array}$ & $4.13 \pm 0.95$ & .339 & .823 & \\
\hline & 5 & $\begin{array}{l}\text { Reflections and glinting arising from the glass. floor. etc. } \\
\text { in the work environment in nurses in terms of occupation }\end{array}$ & $3.72 \pm 0.95$ & .380 & .820 & \\
\hline & 4 & $\begin{array}{l}\text { Noise level in the work environment in nurses in terms of } \\
\text { occupation }\end{array}$ & $4.04 \pm 0.90$ & .471 & .814 & \\
\hline & & Total (17 items) & & & & .826 \\
\hline
\end{tabular}

The factor structure of the developed scale was assessed by using the EFA and varimax rotation method. The factor load value is a coefficient that explains the relation of the items with the factor and to decide the inclusion of items in the scale. The lower limit specified for the factor load value is taken as 0.30 , the load values between 0.30 and 0.59 are considered moderate, and those at 0.60 and above are considered high. ${ }^{[22,23]}$ The present study took into consideration the factor load distribution of the 50-item draft scale and

Published by Sciedu Press

thereafter decided to exclude 33 items with a factor load of less than 0.40 from the scale. Consequently, the factor loads of the items in the ORPS ranged between 0.63 and 0.80 .

It was determined that the ORPS consist of 17 items and 3 sub-dimensions. The presence of 3 sub-dimensions in the scale was supported by the scree plot graph and the amount of variance. The total variance determined after the factor analysis was $51.55 \%$. Since it is not possible to achieve a high variance rate in social sciences, the variance rates rang- 
ing between $40 \%$ and $60 \%$ are considered to be ideal. ${ }^{[16]}$ The ORPS was within acceptable limits in terms of the exploratory factor load value.

The CFA allows for testing hypothesized structures underlying a set of variables and subsequently tells us how well the actual data fit the pre-specified structure. ${ }^{[24]}$ The goodness of chi-square fit in the CFA shows the fit between the population and the sample covariance matrix. The goodness of chi-square fit below 3 corresponds to excellent fit and below 5 to moderate fit. The GFI allows model adaptation to be assessed independent of the sample size and shows to what degree the model assesses the covariance in the sample. The GFI value ranges from 0 to 1 ; a value above 0.95 corresponds to excellent fit and that above 0.90 corresponds to good fit The RMSEA was used to estimate the population covariance and its value ranges between 0 and 1 . The fact that the value taken is zero indicates perfect fit. The CFI is the analysis used to compare the fit of a model determined for the developed scale to another model. Its value ranges between 0 and 1 , and while the value closer to 1 corresponds to perfect fit and that closer to 0 indicates misfit. ${ }^{[25,26]}$ The result of the CFA obtained in this study's fit indices revealed that the model had a good fit.

The next step was determined as 17-item scale's reliability or homogeneity testing for internal consistency. Internal consistency is a reliability method showing that all the units of the developed scale have the feature of measurement of the desired variable. ${ }^{[16]}$ In this study, the internal consistency analysis revealed Cronbach's alpha coefficients. The high Cronbach's alpha coefficient indicates that the items in that scale are consistent with each other. The Cronbach's alpha coefficient within the range of 0.60 to 0.80 indicates that the scale is reliable, and the range of 0.80 to 1.00 indicates that the scale is highly reliable. ${ }^{[20,23]}$ The Cronbach's alpha value of the ORPS was 0.826 . The score showed high reliability of the scale.

Another method used in the internal consistency study of a newly developed scale was item analysis. An item-total correlation analysis explains the correlation between the scores in the items and the total score in the overall scale. If the score in an item is in a positive correlation with the score in the overall scale, that item is discriminating and is admitted into the scale.
According to the literature, correlation coefficient should be 0.30 or higher for items. Thus it can properly distinguish between individuals. ${ }^{[16]}$ The 17-item scale had an item-total correlation coefficient higher than 0.47 .

The scale was evaluated by a test-retest analysis which used to determine whether a quality measured changes over time. Sims stated that the sample for test-retest analysis must have at least 50 members. ${ }^{[27]}$ Therefore, the sample used in the study contained 58 nursing students. For this purpose, the scale is re-applied to the same individuals under the same conditions and at a certain time interval such as 2 to 4 weeks, and the relationship between two measurements is assessed by using the Pearson's Moments Correlation Coefficient technique. ${ }^{[23]}$ The test-retest correlation coefficient is expected to be 0.70 for newly developed scales and at least 0.80 for previously developed and re-used scales. ${ }^{[16]}$ The examination of the relationship between the first and second application results of the scale showed a high positive linear relation between the first and second applications of ORPS in terms of the overall score $(r=.896 ; p=.000)$. This result showed that the ORPS was time invariant and that it measured the same situation.

\section{Conclusion}

Accordingly conclusion of psychometric measurements, the ORPS was found to be valid and reliable for use in Turkey. There is no valid and reliable identification instruments for occupational risk perception in Turkey, therefore we recommend that this scale is used to determine the occupational risk perceptions in students receiving education in the field of healthcare. There is a need for conducting further studies in different cultural settings for scale, so it will be need the long term outcomes of in the future.

\section{ACKNOWLEDGEMENTS}

We wish to thank all of the students at Trakya University Faculty of Health Science, Department of nursing. We also sincerely thank experts who generously shared their thoughts and experiences with us.

\section{CONFlicts of Interest Disclosure}

The authors declare that there is no conflict of interest statement.

[2] Corrao CRN, Mazzotta A, Torre G, et al. Biological risk and occupational health. Industrial Health. 2012; 50(4): 326-337. https: //doi.org/10.2486/indhealth.MS1324

[3] Mirabelli MC, Zock JP, Plana E, et al. Occupational risk factors for asthma among nurses and related healthcare professionals in an in- 
ternational study. Occupational and Environmental Medicine. 2007; 64(7): 474-479. PMid:17332135 https://doi .org/10.1136/oe m. 2006. 031203

[4] Ramsay JD. A New Look at Nursing Safety: The Development and Use of JHAs in the Emergency Department. Journal of SH\&E Research. 2005; 2(2): 2-18.

[5] Karwowski W, Jang RL, Rodrick D, et al. Self-evaluation of biomechanical task demands work environment and perceived risk of injury, by nurses: a field study. Occupational Ergonomics. 2005; 5(1): 13-27.

[6] Dikmen AU, Medeni V, Uslu I, et al. Evaluation of occupational accidents in health care workers working in a university hospital in Ankara. Turkish Journal of Occupational Health \& Safety. 2014; 14(53): 22-29.

[7] Cardoso ACM, De Figueiredo RM. Biological risk in nursing care provided in family health units. Revista Latino-Americana de Enfermagem. 2010; 18(3): 368-72. https://doi.org/10.1590/S010 4-11692010000300011

[8] Braeckman L, Verbrugghe M, Janssens H, et al. Awareness, Knowledge, and Practices Regarding Occupational Hazards Among Medical Students: A Longitudinal Study Before and After Admission as Trainees. Journal of Occupational and Environmental Medicine. 2017; 59 (4): e41-e45. PMid:28252458 https://doi.org/10.1 097/JOM. 0000000000000972

[9] Cruz JP, Colet PC, Al-Otaibi JH, et al. Validity and reliability assessment of the Compliance with Standard Precautions Scale Arabic version in Saudi nursing students. Journal of Infection and Public Health. 2016; 9(5): 645-653. PMid:26947548 https://doi.org/ $10.1016 / j \cdot j i p h .2016 .01 .010$

[10] Gaida JE, Maloney S, Lo K, et al. Clinical incidents involving students on placement: an analysis of incident reports to identify potential risk factors. Physiotherapy. 2015; 101(2): 219225. PMid:25282387 https://doi.org/10.1016/j.physio. 2 014.06 .006

[11] Talas MS. Occupational exposure to blood and body fluids among Turkish nursing students during clinical practice training: frequency of needlestick/sharp injuries and hepatitis B immunisation. Journal of Clinical Nursing. 2009; 18(10): 1394-1403. PMid:19207796 https://doi.org/10.1111/j.1365-2702.2008.02523.x

[12] Magnavita N, Heponiemi T. Workplace violence against nursing students and nurses: an Italian experience. Journal of Nursing Scholarship. 2011; 43(2): 203-210. PMid:21605325 https://doi.org/ $10.1111 / \mathrm{j} .1547-5069.2011 .01392 . \mathrm{x}$

[13] McCarthy MG, Britton JE. A survey of final-year dental, medical and nursing students: occupational injuries and infection control. Journal of the Canadian Dental Association. 2000; 66(10): 561-565. PMid:11091478
[14] Dante A, Natolini M, Graceffa G, et al. The effects of mandatory preclinical education on exposure to injuries as reported by Italian nursing students: a 15-year case-control, multicentre study. Journal of Clinical Nursing. 2014; 23(5-6): 900-904. https ://doi .org/ $10.1111 /$ jocn. 12438

[15] Eljedi A. Prevalence and response to Occupational Hazards among Nursing Students in Gaza Strip, Palestine: The role of Personal Protective Equipment and Safety Regulations. Public Health Research. 2015; 5(1): 32-38.

[16] Sencan H. Reliability and validity in social and behavioral measures First Edition. Ankara: Seckin Publishing. 2005: 51- 788. [Original Work Published In Turkish].

[17] Emiroglu C. Occupational risks and legal regulations in the health sector. Turkish Journal of Occupational Health \& Safety. 2012; 12(43): 16-25 [Original Work Published In Turkish].

[18] Boyer J, Galizzi M, Cifuentes M, et al. Ergonomic and socioeconomic hospital workers' compensation injury claims. American Journal of Industrial Medicine. 2009; 52(7): 551-562. PMid:19479820 https://doi.org/10.1002/ajim. 20702

[19] Lawshe CH. A quantitative approach to content validity. Personnel Psychology. 1975; 28(4): 563-575. https://doi.org/10.1111/ j.1744-6570.1975.tb01393.x

[20] Polit DE, Hungler BP. Nursing Research: Principles and Methods. Seventh Edition. Philadelphia: Lippincott Raven Publishers; 2003.

[21] Ayre C, Scally AJ. Critical values for Lawshe's content validity ratio: revisiting the original methods of calculation. Measurement and Evaluation in Counseling and Development. 2014; 47(1): 79-86. https://doi.org/10.1177/0748175613513808

[22] Abdi H, Williams LJ. Principal component analysis. Wiley interdisciplinary reviews: computational statistics. 2010; 2(4): 433-459. https://doi.org/10.1002/wics.101

[23] Tavsancil E. Measuring attitudes and data analysis with Spss. Fifth edition. Ankara: Nobel Publishing; 2010: 15-155 (Original Work Published In Turkish).

[24] Brown TA. Confirmatory Factor Analysis for Applied Research. Second edition. New York: NY 10012. 2015.

[25] Erkorkmaz U, Etikan I, Demir O, et al. Confirmatory Factor Analysis and Fit Indices: Review. Turkiye Klinikleri Journal of Medical Sciences. 2013; 33(1): 210-23. https://doi.org/10.5336/medsci .2011-26747

[26] Hu L, Bentler PM. Cutoff critaria for fit indexs in coveriance structure analysis: Conventional critaria versus new alternatives, Structural Equation Modeling. 1999; 6: 1-55. https://doi.org/10.1080/ 10705519909540118

[27] Sims RL. Bivariate data analysis: A practical guide. Nova Publishers; 1999. 